\title{
An Investigation of Training Processes and Expectation Levels of Swimming Referees
}

\author{
Canan Gülbin Eskiyecek ${ }^{1}$ \\ ${ }^{1}$ School of Physical Education and Sport, Mardin Artuklu University, Mardin, Turkey \\ Correspondence: Canan Gülbin Eskiyecek, School of Physical Education and Sport, Mardin Artuklu University, \\ Mardin, Turkey.
}

Received: August 23, 2019

Accepted: November 12, 2019

Online Published: December 30, 2019

doi:10.5539/ies.v13n1p54

URL: https://doi.org/10.5539/ies.v13n1p54

\begin{abstract}
This study was aimed to investigate the opinions of licensed swimming referees within the structure of Turkey Swimming Federation about referee training process and determine the level of their expectations. The study group was randomly selected by a total of 212 swimming referees ( 95 female and 117 male), and attended Development Seminar for Swimming Referees which was held in Antalya in 2016. "The Review of Referee Training Process and The Survey of Expectation Levels" developed by Bahadır Kayışoğlu in 2008 was used as a data collection tool in the study. Necessary formal permissions were obtained from Turkish Swimming Federation for the scale applied to the referees. In the analysis of the data, t-test was used for binary comparisons, and one-way analysis of variance (ANOVA) was used for multiple comparisons. SPSS Statistics 24.0 was used in the analysis of the data. The p-value that was less than 0.05 was considered statistically significant. As a result of the research, it was found that some variables of swimming referees (age, gender, classification, professional experience, educational level, satisfaction level and the reasons to become a referee) have impacts on referees' training processes, so it was determined that the referees had both positive and negative opinions regarding the referee training process.
\end{abstract}

Keywords: swimming, refereeing, training process, expectation level

\section{Introduction}

The need for sports, which emerge in every sphere and period of human life, is presented as different sports for people. Swimming is one of the most basic sports branches. Swimming is a sport which is carried out by thousands of people interested in swimming and under the direction of the referees who have received sports and referee training (Dölek, 2010).

Athlete, spectator, referee and manager are the must for all sports branches. Each of them is undoubtedly very important. In addition to this, referees, especially those who struggle with athletes in the field and make decisions that will determine the result of the competition, are the main elements for sports branches. The role of referee in sports competition cannot be denied. In the case of competition in sports, the referee is the expert who can determine right decisions and allocate justice during the competition (Güner, 2009; Karaçam, 2013). Considering the legal personality represented by the referee, the fact that the referee is in the executive position and allocates justice increases the role of referees (Ekmekçi, 2008).

Education, as in many areas, takes an important place in sports and refereeing. An institution that wishes to achieve successful results is obliged to train its own personnel. All institutions and organizations are obliged to provide in-service training. Otherwise, it is inevitable that institutions and organizations will survive (Kayışoğlu, 2008).

Education is one of the prerequisites for the establishment and success of refereeing (Özdemir, 2002). In addition, experience is also the most expensive training process.

In order to be successful in the competitions, the referees should check and develop them in order to update the efficiency of the training they receive in all stages such as regulations, human relations, effective communication, management and organization, effective use of body language, and crisis and conflict management (Karaçam, 2013).

The main task of a swimming referee is to control that rules and regulations are applied during the interview and to ensure that all swimmers have equal and fair competition conditions to the greatest extent possible. The referee 
should make his decisions quickly and decisively, be knowledgeable and ensure that they are fair to all participants. Therefore, the training given to referee is very important, and it is necessary to understand and respond to their expectations.

Unlike all other sports branches, the number of referees involved in swimming competitions is quite high. It is very important that these referees run in a responsible and disciplined manner. In this context, this study is aimed to examine the opinions of licensed swimming referees within the structure of Turkey Swimming Federation about referee training process and determine the level of their expectations.

\section{Methods}

\subsection{Research Model}

In the study, descriptive research approach is used as basic research method. Descriptive survey models, which are one of the quantitative research types, are research models which aim to investigate the current situation in a subject.

\subsection{Research Group}

Research group is composed of 6 FINA, 74 National and 132 Provincial swimming referees, a total of 212 swimming referees (95 female and 117 male), who actively serve in Turkey, and attended Development Seminar for Swimming Referees which was held between 10th-13rd March 2016 in Antalya.

\subsection{Methods of Data Collection}

In this research, "Survey" method was used for the collection of data. The data used in the research were obtained by the researcher personally by conducting a questionnaire to individuals who attended Development Seminar for Swimming Referees in Antalya. Necessary formal permissions were obtained from Turkish Swimming Federation for the scale applied to the referees.

The questionnaire used in the research, "The Review of Referee Training Process and The Survey of Expectation Levels", was developed by Bahadır KAYIŞOĞLU in 2008. Accordingly, it can be mentioned that the tool used is reliable. In this context, the survey data were obtained from the "Examination of the training process of swimming referees and their expectation levels". The Cronbach's alpha value $(\alpha)$ was 819 for the 29 -Item part of the questionnaire, which was prepared by using 5-point Likert scale.

The data collection tool used in the study was based around a core set of 6 sections including demographic information. In the first part of the questionnaire, there are 9 questions about the demographic information of the referees, in the second part there are 2 questions about the opinions of the referees about candidate referee training courses, in the third part there are 8 questions about the opinions of the referees about the proficiency of instructors, in the fourth part there are 4 questions about the opinions of the referees on the efficiency of the educational environment, in the fifth part there are 14 questions about the opinions of the referees on the planning of the training seminars, and in the sixth part there is one question about the opinions of referees on the evaluation of the training seminars. The respondents are asked to pick only one answer.

\subsection{Data Analysis}

SPSS Statistics 24.0 was used in the analysis of the data. The frequency (f) and percentage (\%) distributions of the information obtained from the questions in the demographic information part of the questionnaire were examined and Mean $\pm \mathrm{Sd}$ was calculated for descriptive statistics. In other parts of the questionnaire, t-test and one-way ANOVA were used. LSD test was used for homogeneous variances and Tamhane Test was used for non-homogeneous groups. In addition, ANOVA test was applied for the variables in the subgroups that variables were separately collected according to the groups. The p-value that was less than 0.05 was considered statistically significant.

\section{Results}

The findings of the research results are presented in the tables below and evaluated. 
Table 1. Percentage frequency distribution of demographic information of the research group

\begin{tabular}{|c|c|c|c|c|}
\hline Variables & Rank & Subcategories & Frequency (f) & Percentage $(\%)$ \\
\hline \multirow{5}{*}{ Age } & 1 & 22 years and under & 13 & 6.1 \\
\hline & 2 & 23-26 years & 35 & 16.5 \\
\hline & 3 & $27-30$ years & 33 & 15.6 \\
\hline & 4 & 31-34 years & 16 & 7.5 \\
\hline & 5 & 35 years and above & 115 & 54.2 \\
\hline \multirow{2}{*}{ Gender } & 1 & Female & 95 & 44.8 \\
\hline & 2 & Male & 117 & 55.2 \\
\hline \multirow{2}{*}{ Marital Status } & 1 & Married & 110 & 52.4 \\
\hline & 2 & Single & 101 & 47.6 \\
\hline \multirow{3}{*}{ Classifications } & 1 & Provincial Referee & 132 & 62.3 \\
\hline & 2 & National Referee & 74 & 34.9 \\
\hline & 3 & FINA & 6 & 2.8 \\
\hline \multirow{7}{*}{ Professional Experience } & 1 & $1-3$ years & 74 & 34.9 \\
\hline & 2 & 4-6 years & 40 & 18.9 \\
\hline & 3 & $7-9$ years & 14 & 6.6 \\
\hline & 4 & $10-12$ years & 19 & 9.0 \\
\hline & 5 & $13-15$ years & 11 & 5.2 \\
\hline & 6 & $16-18$ years & 8 & 3.8 \\
\hline & 7 & 19 years and above & 46 & 21.7 \\
\hline \multirow{5}{*}{ Education Level } & 1 & High School & 51 & 24.1 \\
\hline & 2 & Associate Degree & 106 & 50.0 \\
\hline & 3 & Bachelor's Degree & 34 & 16.0 \\
\hline & 4 & Master's Degree & 20 & 9.4 \\
\hline & 5 & Doctorate & 1 & 0.5 \\
\hline \multirow{5}{*}{ The Reasons to Become a Referee } & 1 & Social Activity & 64 & 30.2 \\
\hline & 2 & Popularity & - & - \\
\hline & 3 & Ex-swimmer & 32 & 15.1 \\
\hline & 4 & Additional Work & 7 & 3.3 \\
\hline & 5 & Passion & 109 & 51.4 \\
\hline \multirow{4}{*}{ Satisfaction Level } & 1 & Satisfied & 205 & 96.7 \\
\hline & 2 & Undecided & 7 & 3.3 \\
\hline & 3 & Not Satisfied & - & - \\
\hline & & Total & 212 & 100 \\
\hline
\end{tabular}

As seen in Table $1,44.8 \%$ of the participants were female and $55.2 \%$ of those were male; $52.4 \%$ of the participants were married and $47.6 \%$ of those were single. When the demographic information of the research group is examined, it is seen that $54.2 \%$ of the participants were 35 years of age and older, $62.3 \%$ of the participants were provincial referee, $34.9 \%$ of the participants had $1-3$ years professional experience, $21.7 \%$ of the participants had more than 19 years professional experience. When educational levels of participants are considered, it is also observed that $50 \%$ of the participants completed associate degree. In addition, $51.4 \%$ of the participants serve as a referee because they refereeing as passion, and $96.7 \%$ of them are satisfied to be a referee. 
Table 2. Percentage frequency distribution related to referees' opinion on the efficiency of candidate

\begin{tabular}{|c|c|c|c|c|c|c|c|c|c|c|c|}
\hline \multirow{2}{*}{$\begin{array}{l}\text { Opinions } \\
\text { Items on the Efficiency of Candidate Referee Training Courses }\end{array}$} & \multirow[b]{2}{*}{$\mathrm{N}$} & \multicolumn{2}{|c|}{ 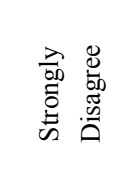 } & \multicolumn{2}{|c|}{ 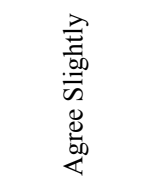 } & \multicolumn{2}{|c|}{ 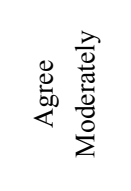 } & \multicolumn{2}{|c|}{ 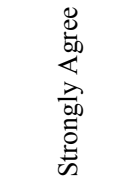 } & \multicolumn{2}{|c|}{ 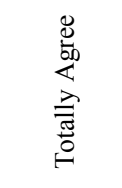 } \\
\hline & & $\mathrm{f}$ & $\%$ & $\mathrm{f}$ & $\%$ & $\mathrm{f}$ & $\%$ & $\mathrm{f}$ & $\%$ & $\mathrm{f}$ & $\%$ \\
\hline $\begin{array}{l}\text { 1. Adequate practical training is provided in candidate referee } \\
\text { training courses }\end{array}$ & 212 & - & - & 7 & 3.3 & 68 & 32.1 & 71 & 33.5 & 66 & 31.1 \\
\hline $\begin{array}{l}\text { 2. The number of trainees in candidate referee training courses is } \\
\text { suitable for a good educational environment }\end{array}$ & 212 & 70 & 33.0 & 82 & 38.7 & 25 & 11.8 & 20 & 9.4 & 15 & 7.1 \\
\hline
\end{tabular}
$* \mathrm{p}<0.05$.

When referees' opinion on the efficiency of candidate referee training courses are examined in Table 2, it is seen that the referees report positive opinion in I-1 (Item 1), but negative opinion in I-2. Participation percentages of these items are $64.6 \%$ in I-1 and $71.7 \%$ in I-2, respectively.

Table 3. Percentage frequency distribution related to referees' opinion on proficiency of instructors

\begin{tabular}{|c|c|c|c|c|c|c|c|c|c|c|c|}
\hline Opinions & & $\begin{array}{l}\vec{\partial} \\
\overrightarrow{0} \\
\overrightarrow{0} \\
\overrightarrow{0}\end{array}$ & 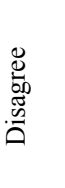 & & 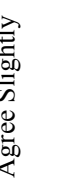 & & $\begin{array}{l}\frac{\lambda}{0} \\
\frac{\pi}{\pi} \\
\frac{3}{0} \\
0 \\
\Sigma\end{array}$ & & 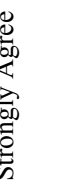 & & 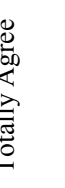 \\
\hline Items on the Proficiency of Instructors & $\mathrm{N}$ & $\mathrm{f}$ & $\%$ & $\mathrm{f}$ & $\%$ & $\mathrm{f}$ & $\%$ & $\mathrm{f}$ & $\%$ & $\mathrm{f}$ & $\%$ \\
\hline $\begin{array}{l}\text { 3. Instructors are willing to work overtime with referees when } \\
\text { needed }\end{array}$ & 212 & 1 & 0.5 & 8 & 3.8 & 38 & 17.9 & 37 & 31.6 & 98 & 46.2 \\
\hline $\begin{array}{l}\text { 4. Instructors are aware of individual differences of the referees, } \\
\text { and they plan course accordingly }\end{array}$ & 212 & 79 & 37.3 & 89 & 42.0 & 24 & 11.3 & 18 & 8.5 & 2 & 0.9 \\
\hline 5. Instructors plan and implement course activities at a high level & 212 & 141 & 66.5 & 54 & 25.5 & 6 & 2.8 & 7 & 3.3 & 4 & 1.9 \\
\hline $\begin{array}{l}\text { 6. Instructors influence referees with their positive attitudes and } \\
\text { behaviors }\end{array}$ & 212 & 133 & 62.7 & 44 & 20.8 & 15 & 7.1 & 12 & 5.7 & 8 & 3.8 \\
\hline $\begin{array}{l}\text { 7. Instructors give importance to the opinions and ideas of the } \\
\text { referees }\end{array}$ & 212 & 103 & 48.6 & 63 & 29.7 & 27 & 12.7 & 15 & 7.1 & 4 & 1.9 \\
\hline $\begin{array}{l}\text { 8. Instructors provide an enjoyable time with activities planned } \\
\text { in the educational environment }\end{array}$ & 212 & 18 & 8.5 & 26 & 12.3 & 63 & 29.7 & 54 & 25.5 & 51 & 24.1 \\
\hline $\begin{array}{l}\text { 9. Instructors who take part in training seminars have academic } \\
\text { knowledge and experience appropriate to the seminar }\end{array}$ & 212 & 3 & 1.4 & 6 & 2.8 & 43 & 20.3 & 77 & 36.3 & 83 & 39.2 \\
\hline $\begin{array}{l}\text { 10. Instructors use different learning and teaching methods in } \\
\text { training seminars }\end{array}$ & 212 & 101 & 47.6 & 80 & 37.7 & 13 & 6.1 & 14 & 6.6 & 4 & 1.9 \\
\hline
\end{tabular}
$* \mathrm{p}<0.05$

When referees' opinions on the proficiency of the instructors are examined in Table 3, the items that report positive opinion are I-3 and I-9, respectively. The percentage of referees' participation in these items is $77.8 \%$ and $75.5 \%$, respectively. The items reporting negative opinions are I-4, I-5, I-6, I-7 and I-10, respectively. Participation percentages of these items are $79.8 \%, 92.0 \%, 83.5 \%, 78.3 \%$ and $85.3 \%$, respectively. 
Table 4. Percentage frequency distribution related to referees' opinion on educational environment

\begin{tabular}{|c|c|c|c|c|c|c|c|c|c|c|c|}
\hline Opinions & & & 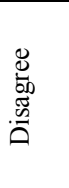 & & 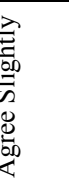 & & 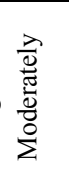 & & 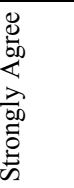 & & 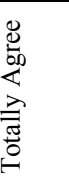 \\
\hline Items on the Efficiency of Educational Environment & $\mathrm{N}$ & $\mathrm{f}$ & $\%$ & $\mathrm{f}$ & $\%$ & $\mathrm{f}$ & $\%$ & $\mathrm{f}$ & $\%$ & $\mathrm{f}$ & $\%$ \\
\hline $\begin{array}{l}\text { 11. The buildings and facilities owned by the institution are } \\
\text { suitable for education }\end{array}$ & 212 & 79 & 37.3 & 87 & 41.0 & 26 & 12.3 & 13 & 6.1 & 7 & 3.3 \\
\hline $\begin{array}{l}\text { 12. The seminar building, and equipment are well organized for } \\
\text { the use of instructors and referees }\end{array}$ & 212 & 121 & 57.1 & 54 & 25.5 & 19 & 9.0 & 11 & 5.2 & 7 & 3.3 \\
\hline $\begin{array}{l}\text { 13. The referees participating in the training seminars create a } \\
\text { good educational environment among themselves }\end{array}$ & 212 & 8 & 3.8 & 29 & 13.7 & 63 & 29.7 & 55 & 25.9 & 57 & 26.9 \\
\hline $\begin{array}{l}\text { 14. The physical structure of the classroom environments where } \\
\text { training seminars are conducted is suitable for good education }\end{array}$ & 212 & 83 & 39.2 & 58 & 27.4 & 30 & 14.2 & 22 & 14.2 & 19 & 9.0 \\
\hline
\end{tabular}

$* \mathrm{p}<0.05$.

When referees' opinions on the efficiency of the educational environment are examined in Table 4, the items that report negative opinions are I-11, I-12 and I-14, respectively. Percentage of participation in these items is $78.3 \%$, $82.6 \%$ and $66.6 \%$, respectively.

Table 5. Percentage Frequency distribution related to referees' opinion on planning of training seminars

\begin{tabular}{|c|c|c|c|c|c|c|c|c|c|c|c|}
\hline \multirow{2}{*}{$\begin{array}{l}\text { Opinions } \\
\text { Items on Planning of Training Seminars }\end{array}$} & \multirow[b]{2}{*}{$\mathrm{N}$} & \multicolumn{2}{|c|}{ 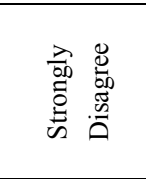 } & \multicolumn{2}{|c|}{ 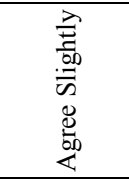 } & \multicolumn{2}{|c|}{ 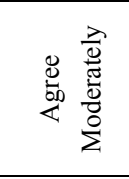 } & \multicolumn{2}{|c|}{ 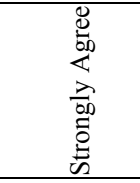 } & \multicolumn{2}{|c|}{ 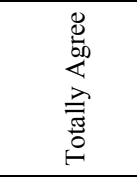 } \\
\hline & & f & $\%$ & f & $\%$ & $\mathrm{f}$ & $\%$ & $\mathrm{f}$ & $\%$ & f & $\%$ \\
\hline 15. The objectives of the training seminar are clearly defined & 212 & 3 & 1.4 & 3 & 1.4 & 26 & 12.3 & 54 & 5.5 & 126 & 59.4 \\
\hline $\begin{array}{l}\text { 16. The courses given in the training seminars are clear and } \\
\text { understandable }\end{array}$ & 212 & 152 & 71.7 & 44 & 20.8 & 7 & 3.3 & 5 & 2.4 & 4 & 1.9 \\
\hline $\begin{array}{l}\text { 17. Different abilities and educational levels of referees are } \\
\text { taken into consideration during the preparation and conduction } \\
\text { of training seminars }\end{array}$ & 212 & 118 & 55.7 & 52 & 24.5 & 22 & 10.4 & 7 & 3.3 & 13 & 6.1 \\
\hline 18. The date of training seminars is suitable for referees & 212 & 9 & 4.2 & 31 & 14.6 & 72 & 34.0 & 45 & 21.2 & 55 & 25.9 \\
\hline $\begin{array}{l}\text { 19. Managers, instructors and referees are aware of the program } \\
\text { activities conducted within the institution }\end{array}$ & 212 & 2 & 0.9 & 22 & 10.4 & 65 & 30.7 & 80 & 37.7 & 43 & 20.3 \\
\hline $\begin{array}{l}\text { 20. Managers, instructors and referees collectively participate } \\
\text { in the decision-making process related to training seminars } \\
\text { within the institution }\end{array}$ & 212 & 6 & 2.8 & 29 & 13.7 & 53 & 25.0 & 70 & 33.0 & 54 & 25.5 \\
\hline $\begin{array}{l}\text { 21. Training seminar program is organized to improve } \\
\text { teamwork skills }\end{array}$ & 212 & 12 & 5.7 & 36 & 17.0 & 69 & 32.5 & 59 & 27.8 & 36 & 17.0 \\
\hline $\begin{array}{l}\text { 22. Opinions of the experts were taken during the planning of } \\
\text { training program }\end{array}$ & 212 & 3 & 1.4 & 28 & 13.2 & 67 & 31.6 & 80 & 37.7 & 34 & 16.0 \\
\hline $\begin{array}{l}\text { 23. Courses given in training seminars are planned in an } \\
\text { orderly manner }\end{array}$ & 212 & 3 & 1.4 & 16 & 7.5 & 49 & 23.1 & 90 & 42.5 & 54 & 25.5 \\
\hline $\begin{array}{l}\text { 24. Various measurement tools were used to determine the } \\
\text { needs of the referees during the preparation of training } \\
\text { programs }\end{array}$ & 212 & 1 & 0.5 & 18 & 8.5 & 58 & 27.4 & 79 & 37.3 & 56 & 26.4 \\
\hline $\begin{array}{l}\text { 25. Managers exhibit positive attitudes and behaviors in solving } \\
\text { problems related to the training seminar }\end{array}$ & 212 & 2 & 0.9 & 9 & 4.2 & 53 & 25.0 & 86 & 40.6 & 62 & 29.2 \\
\hline $\begin{array}{l}\text { 26. The training program in the seminars is clearly identified } \\
\text { and submitted to the referees' information }\end{array}$ & 212 & 2 & 0.9 & 3 & 1.4 & 32 & 15.1 & 84 & 39.6 & 91 & 42.9 \\
\hline $\begin{array}{l}\text { 27. Introductory documents are prepared for each training } \\
\text { seminar }\end{array}$ & 212 & 4 & 1.9 & 26 & 12.3 & 91 & 42.9 & 53 & 25.0 & 38 & 17.9 \\
\hline
\end{tabular}


28. The content of the training seminars is enough to meet the deficiencies of the referees

$\begin{array}{lllllllllll}212 & 17 & 8.0 & 29 & 13.7 & 71 & 33.5 & 57 & 26.9 & 38 & 17.9\end{array}$

$* \mathrm{p}<0.05$.

When referees' opinion on the planning of the training seminars are examined in Table 5, the items that express positive opinion are I-15, I-19, I-22, I-23, I-24, I-25 and I-26, respectively. The percentages of participation in these items are $64.9 \%, 58 \%, 53.7 \%, 67 \%, 63.7 \%, 69.8 \%, 82.5 \%$ and $75.5 \%$, respectively. Items reporting negative opinions are I-16 and I-17, respectively. The percentage of referees' participation in these items is $92.5 \%$ and $80.2 \%$, respectively.

Table 6. Percentage frequency distribution related to referees' opinion on evaluation of training seminars

\begin{tabular}{|c|c|c|c|c|c|c|c|c|c|c|c|}
\hline Opinions & & & 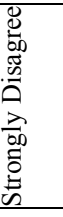 & & 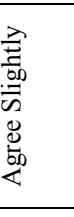 & & 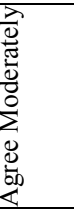 & & 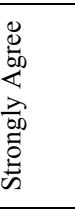 & & 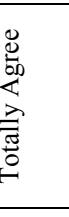 \\
\hline Items on Evaluation of Training Seminars & $\mathrm{N}$ & $\mathrm{f}$ & $\%$ & $\mathrm{f}$ & $\%$ & $\mathrm{f}$ & $\%$ & $\mathrm{f}$ & $\%$ & $\mathrm{f}$ & $\%$ \\
\hline 29. Evaluation activities are carried out at the end of implementation & 212 & 7 & 3.3 & 27 & 12.7 & 58 & 27.4 & 63 & 29.7 & 57 & 26.9 \\
\hline
\end{tabular}

When referees' opinions on the training seminars are examined in Table 6, it is seen that the referees give a positive opinion in I-29. The percentage of referees' participation in this item is $56.6 \%$.

Table 7. One-way ANOVA test results related to professional experience of swimming referees

\begin{tabular}{|c|c|c|c|c|c|c|}
\hline Opinions & Experience & $\mathrm{N}$ & $\mathrm{X}$ & $\mathrm{Sd}$ & $\mathrm{F}$ & $\mathrm{p}$ \\
\hline \multirow{8}{*}{$\begin{array}{l}\text { Opinions on Planning of } \\
\text { Training Seminars }\end{array}$} & $1-3$ years & 74 & 46.6757 & 7.15792 & \multirow{8}{*}{3.333} & \multirow{8}{*}{$.004 *$} \\
\hline & $4-6$ years & 40 & 50.6250 & 8.72276 & & \\
\hline & 7-9 years & 14 & 42.8571 & 7.63451 & & \\
\hline & $10-12$ years & 19 & 44.6316 & 8.34806 & & \\
\hline & $13-15$ years & 11 & 52.0000 & 9.14330 & & \\
\hline & $16-18$ years & 8 & 50.8750 & 5.11126 & & \\
\hline & 19 years and above & 46 & 48.7174 & 8.30706 & & \\
\hline & Total & 212 & 47.8632 & 8.17377 & & \\
\hline
\end{tabular}

Least Significant Difference (LSD) Test

According to duration of refereeing, significant difference was observed between 1-3 and 4-6 years, 1-3 and 13-15 years, 4-6 and 7-9 years, 4-6 and 10-12 years, 7-9 and 13-15 years, 7-9 and 16-18 years, 7-9 and 19 years and above, and 10-12 and 13-15 years

$* \mathrm{p}<0.05$.

In Table 7, significant differences were found in the comparison of referees' opinion on the planning of the training seminars and the duration of refereeing $(\mathrm{p}<0.05)$, and this difference was observed between 1-3 and 4-6 years, 1-3 and $13-15$ years, $4-6$ and 7-9 years, $4-6$ and $10-12$ years, 7-9 and $13-15$ years, 7-9 and $16-18$ years, $7-9$ and 19 years and above, and $10-12$ and 13-15 years. 
Table 8. One-way ANOVA test results according to the variable of educational level of swimming referees

\begin{tabular}{ccccccc}
\hline Opinions & Educational Level & $\mathrm{N}$ & $\mathrm{X}$ & $\mathrm{Sd}$ & $\mathrm{F}$ & $\mathrm{p}$ \\
\hline & High School & 51 & 10.5098 & 3.33690 & & \\
Opinions on the Efficiency of the & Associate Degree & 34 & 9.5294 & 2.31249 & & \\
Educational Environment & Bachelor's Degree & 107 & 8.9439 & 2.18844 & 4.204 & $.007^{*}$ \\
& Master's Degree & 20 & 9.9000 & 3.37015 & & \\
& Total & 212 & 9.5047 & 2.70597 & \\
\hline
\end{tabular}

Difference (Tamhane Test)

In terms of the variable of educational level, significant difference was found between high school and bachelor's degree

$* \mathrm{p}<0.05$.

In Table 8, significant difference was found between high school graduates and bachelor's degree graduates when comparing the opinions of the referees on the efficiency of educational environment and educational level $(\mathrm{p}<0.05)$.

Table 9. T-test results related to the variable of satisfaction level of swimming referees

\begin{tabular}{ccccccc}
\hline Opinions & Satisfaction Level & $\mathrm{N}$ & $\mathrm{X}$ & $\mathrm{Sd}$ & $\mathrm{t}$ & $\mathrm{p}$ \\
\hline \multirow{2}{*}{ Opinions on Planning of Training } & Satisfied & 205 & 48.0780 & 8.15979 & & \\
Seminars & Undecided & 7 & 41.5714 & 6.16055 & 2.087 & $.038^{*}$ \\
& Total & 212 & 47.8632 & 8.17377 & & \\
\hline
\end{tabular}

$* \mathrm{p}<0.05$.

In Table 9, significant difference was found between referees' opinion on the variables of planning of the training seminars and satisfaction levels of referees $(p<0.05)$. It was observed that average of those who are satisfied to be referee is higher than the average of undecided ones.

Table 10. One-way ANOVA test results related to the variable of age of swimming referees

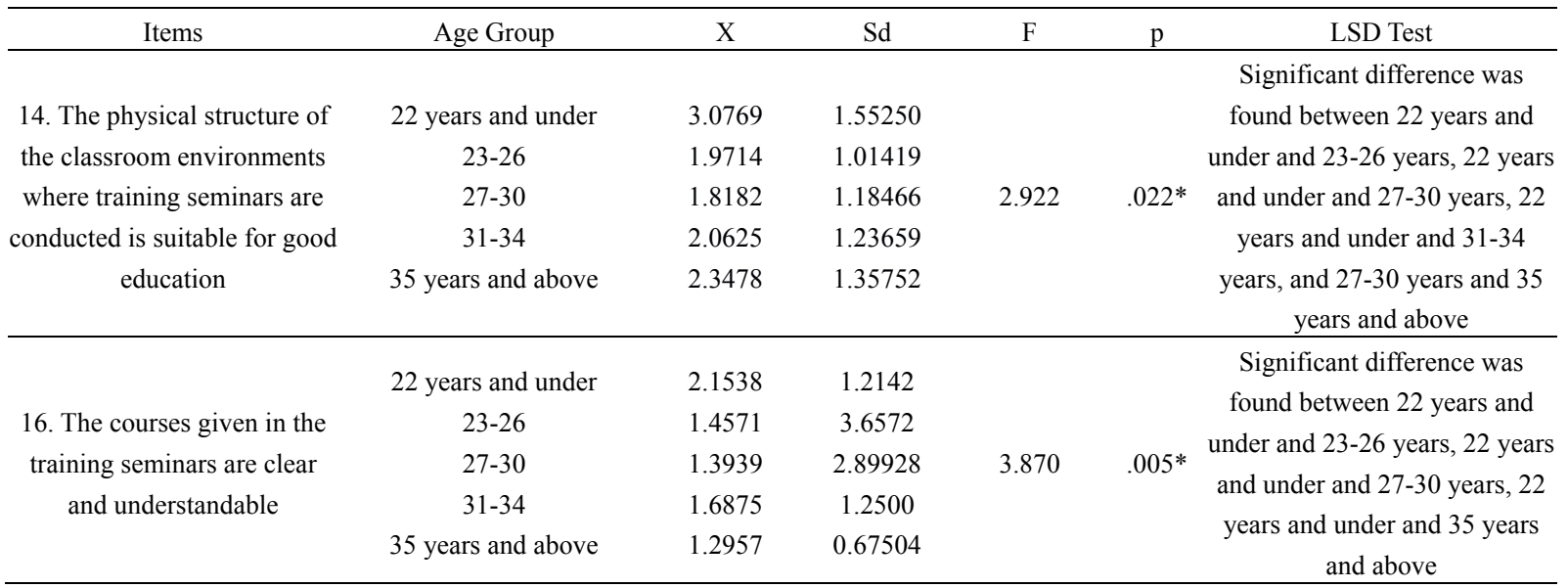

$* \mathrm{p}<0.05$.

In Table 10, it was observed that there was a significant difference between the variable of age, and the referees' opinion that the physical structure of the classroom environments where training seminars are conducted is suitable for good education $(\mathrm{p}<0.05)$, and this difference was observed between 22 years and under, and 23-26 years; 22 years and under, and 27-30 years; 22 years and under, and 31-34 years; and 27-30 years, and 35 years and above.

In Table 10, it was observed that there was a significant difference between the variable of age, and the referees' opinion that the courses given in the training seminars are clear and understandable $(p<0.05)$, and this difference was observed between 22 years and under, and 23-26 years; 22 years and under, and 27-30 years; 22 years and 
under, and 35 years and above.

Table 11. T-test results related to gender variable of swimming referees

\begin{tabular}{cccccc}
\hline Items & Gender & $\mathrm{X}$ & $\mathrm{Sd}$ & $\mathrm{t}$ & $\mathrm{p}$ \\
\hline 22. Opinions of the experts were taken & Female & 3.6842 & .95942 & \multirow{2}{*}{2.015} & \multirow{2}{*}{$.045^{*}$} \\
during the planning of training program & Male & 3.4188 & .94904 & & \\
\hline
\end{tabular}

$*$ p $<0.05$.

In Table 11, it was observed that there was a significant difference between the variable of gender, and the referees' opinion that opinions of the experts were taken during the planning of training program $(\mathrm{p}<0.05)$ and accordingly, it was observed that female referees participated in the opinion of the experts more than the male referees in terms of planning of the program.

Table 12. One-way ANOVA test results related to the variable of classification of swimming referees

\begin{tabular}{ccccccc}
\hline Items & Classifications & $\mathrm{X}$ & $\mathrm{Sd}$ & $\mathrm{F}$ & $\mathrm{p}$ & Difference (LSD) \\
\hline $\begin{array}{c}\text { 23. Courses given in } \\
\text { training seminars are }\end{array}$ & Provincial & 3.7121 & .96922 & & & $\begin{array}{c}\text { Significant difference was found } \\
\text { between Provincial and National } \\
\text { planned in an orderly } \\
\text { manner }\end{array}$ \\
$\begin{array}{c}\text { International (FINA) } \\
\text { Refees }\end{array}$
\end{tabular}

In Table 12, it was observed that there was a significant difference between the variable of referees' classification, and the referees' opinion that lessons given in training seminars are planned in an orderly manner $(p<0.05)$, and this difference was observed between the provincial and national referees.

Table 13. One-way ANOVA test results related to variable of professional experience of swimming referees

\begin{tabular}{|c|c|c|c|c|c|c|}
\hline Items & Professional Experience & $\mathrm{X}$ & $\mathrm{Sd}$ & $\mathrm{F}$ & $\mathrm{P}$ & Difference (LSD) \\
\hline \multirow{7}{*}{$\begin{array}{l}\text { 1. Adequate practical } \\
\text { training is provided in } \\
\text { referee training courses }\end{array}$} & $1-3$ years & 3.7432 & .84498 & \multirow{7}{*}{2.152} & \multirow{7}{*}{$.049 *$} & \multirow{7}{*}{$\begin{array}{c}\text { Significant difference was found between } \\
1-3 \text { and } 4-6 \text { years, } 4-6 \text { and } 10-12 \text { years, } 4-6 \\
\text { years and } 19 \text { years and above }\end{array}$} \\
\hline & 4-6 years & 4.3250 & .82858 & & & \\
\hline & $7-9$ years & 3.8571 & .86444 & & & \\
\hline & $10-12$ years & 3.8421 & .89834 & & & \\
\hline & $13-15$ years & 4.0909 & .94388 & & & \\
\hline & $16-18$ years & 4.0000 & .75593 & & & \\
\hline & 19 years and above & 3.8696 & .88465 & & & \\
\hline \multirow{7}{*}{$\begin{array}{l}\text { 8. Instructors provide an } \\
\text { enjoyable time with } \\
\text { activities planned in the } \\
\text { educational environment }\end{array}$} & $1-3$ years & 3.3108 & 1.18120 & \multirow{7}{*}{3.468} & \multirow{7}{*}{$.003 *$} & \multirow{7}{*}{$\begin{array}{c}\text { Significant difference was found between } \\
1-3 \text { and } 4-6 \text { years, } 1-3 \text { and } 13-15 \text { years, } 4-6 \\
\text { and } 10-12 \text { years, } 10-12 \text { and } 13-15 \text { years, } \\
13-15 \text { and } 16-18 \text { years, } 4-6 \text { years and } 19 \\
\text { years and above, and } 13-15 \text { years and } 19 \\
\text { years and above }\end{array}$} \\
\hline & 4-6 years & 3.9750 & 1.09749 & & & \\
\hline & 7-9 years & 3.5000 & .94054 & & & \\
\hline & $10-12$ years & 3.1579 & 1.16729 & & & \\
\hline & $13-15$ years & 4.3636 & .80904 & & & \\
\hline & $16-18$ years & 3.2500 & 1.03510 & & & \\
\hline & 19 years and above & 3.1087 & .38609 & & & \\
\hline \multirow{7}{*}{$\begin{array}{l}\text { 13. The referees } \\
\text { participating in the } \\
\text { training seminars create } \\
\text { good educational } \\
\text { environment among } \\
\text { themselves }\end{array}$} & $1-3$ years & 3.3919 & 1.14458 & \multirow{7}{*}{2.328} & \multirow{7}{*}{$.034 *$} & \multirow{7}{*}{$\begin{array}{l}\text { Significant difference was found between } \\
1-3 \text { and } 4-6 \text { years, } 4-6 \text { and } 10-12 \text { years, } 7-9 \\
\text { and } 10-12 \text { years, } 10-12 \text { and } 13-15 \text { years }\end{array}$} \\
\hline & 4-6 years & 3.9250 & .97106 & & & \\
\hline & $7-9$ years & 3.9286 & .99725 & & & \\
\hline & $10-12$ years & 3.0526 & 1.26814 & & & \\
\hline & $13-15$ years & 4.0909 & 1.04447 & & & \\
\hline & $16-18$ years & 3.5000 & 1.19523 & & & \\
\hline & 19 years and above & 3.6087 & 1.14462 & & & \\
\hline \multirow{4}{*}{$\begin{array}{l}\text { 21. Training seminar } \\
\text { program is organized to } \\
\text { improve teamwork skills }\end{array}$} & $1-3$ years & 3.1892 & 1.14288 & \multirow{4}{*}{3.704} & \multirow{4}{*}{$.002 *$} & \multirow{4}{*}{$\begin{array}{l}\text { Significant difference was found between } \\
1-3 \text { and } 4-6 \text { years, } 1-3 \text { and } 13-15 \text { years, } 4-6 \\
\text { and 7-9 years, } 4-6 \text { and } 10-12 \text { years, } 7-9 \\
\text { and } 13-15 \text { years, } 7-9 \text { and } 16-18 \text { years, }\end{array}$} \\
\hline & 4-6 years & 3.7000 & .99228 & & & \\
\hline & $7-9$ years & 2.6429 & 1.15073 & & & \\
\hline & $10-12$ years & 2.7895 & 1.08418 & & & \\
\hline
\end{tabular}




\begin{tabular}{|c|c|c|c|c|c|c|}
\hline & $13-15$ years & 4.0000 & 1.09545 & & & $10-12$ and $13-15$ years, $7-9$ years and 19 \\
\hline & $16-18$ years & 3.6250 & .51755 & & & years and above, and 10-12 years and 19 \\
\hline & 19 years and above & 3.4783 & 1.06956 & & & years and above \\
\hline \multirow{7}{*}{$\begin{array}{l}\text { 22. Opinions of the } \\
\text { experts were taken } \\
\text { during the planning of } \\
\text { training program }\end{array}$} & $1-3$ years & 3.2838 & .89932 & \multirow{7}{*}{4.276} & \multirow{7}{*}{$.000^{*}$} & Significant difference was found between \\
\hline & 4-6 years & 3.9000 & 1.08131 & & & $1-3$ and $4-6$ years, $1-3$ and $13-15$ years, $1-3$ \\
\hline & $7-9$ years & 3.0000 & .87706 & & & years and 19 years and above, $4-6$ and 7-9 \\
\hline & $10-12$ years & 3.2105 & .91766 & & & years, $4-6$ and $10-12$ years, $7-9$ and $13-15$ \\
\hline & $13-15$ years & 4.0000 & .89443 & & & years, $7-9$ and $16-18$ years, $10-12$ and \\
\hline & $16-18$ years & 3.8750 & .64087 & & & $13-15$ years, $7-9$ years and 19 years and \\
\hline & 19 years and above & 3.7609 & .84813 & & & $\begin{array}{l}\text { above, and } 10-12 \text { years and } 19 \text { years and } \\
\text { above }\end{array}$ \\
\hline \multirow{7}{*}{$\begin{array}{l}\text { 23. Courses given in } \\
\text { training seminars are } \\
\text { planned in an orderly } \\
\text { manner }\end{array}$} & $1-3$ years & 3.5946 & .93514 & \multirow{7}{*}{3.994} & \multirow{7}{*}{$.001^{*}$} & Significant difference was found between \\
\hline & 4-6 years & 4.2250 & .89120 & & & $1-3$ and $4-6$ years, $1-3$ and $13-15$ years, $1-3$ \\
\hline & 7-9 years & 3.6429 & .84190 & & & years and 19 years and above, 4-6 and 7-9 \\
\hline & $10-12$ years & 3.2105 & 1.03166 & & & years, $4-6$ and $10-12$ years, $7-9$ and $13-15$ \\
\hline & $13-15$ years & 4.4545 & .68755 & & & years, $10-12$ and $13-15$ years, $10-12$ and \\
\hline & $16-18$ years & 4.2500 & .70711 & & & $16-18$ years, and $10-12$ years and 19 years \\
\hline & 19 years and above & 3.9565 & .84213 & & & and above \\
\hline \multirow{7}{*}{$\begin{array}{l}\text { 24. Various measurement } \\
\text { tools were used to } \\
\text { determine the needs of } \\
\text { the referees during the } \\
\text { preparation of training } \\
\text { programs }\end{array}$} & $1-3$ years & 3.7432 & .87681 & \multirow{7}{*}{3.946} & \multirow{7}{*}{$.001 *$} & Significant difference was found between \\
\hline & $4-6$ years & 4.2250 & .91952 & & & $1-3$ and $4-6$ years, $1-3$ and $7-9$ years, $1-3$ \\
\hline & 7-9 years & 3.2143 & .89258 & & & and $10-12$ years, $4-6$ and $7-9$ years, $4-6$ \\
\hline & $10-12$ years & 3.2632 & 1.04574 & & & and $10-12$ years, $7-9$ and $13-15$ years, $7-9$ \\
\hline & $13-15$ years & 4.1818 & .75076 & & & years and 19 years and above, $10-12$ and \\
\hline & $16-18$ years & 3.7500 & .70711 & & & $13-15$ years, and $10-12$ years and 19 years \\
\hline & 19 years and above & 3.8696 & .93354 & & & and above \\
\hline \multirow{7}{*}{$\begin{array}{c}\text { 25. Managers exhibit } \\
\text { positive attitudes and } \\
\text { behaviors in solving } \\
\text { problems related to the } \\
\text { training seminar }\end{array}$} & $1-3$ years & 3.8243 & .76495 & \multirow{7}{*}{5.138} & \multirow{7}{*}{$.000^{*}$} & \multirow{7}{*}{$\begin{array}{l}\text { Significant difference was found between } \\
1-3 \text { and 4-6 years, } 1-3 \text { and } 10-12 \text { years, } 4-6 \\
\text { and 7-9 years, } 4-6 \text { and } 10-12 \text { years, } 7-9 \\
\text { and } 13-15 \text { years, } 7-9 \text { and } 16-18 \text { years, } 7-9 \\
\text { years and } 19 \text { years and above, } 10-12 \text { and } \\
13-15 \text { years, } 10-12 \text { and } 16-18 \text { years, and } \\
10-12 \text { years and } 19 \text { years and above }\end{array}$} \\
\hline & 4-6 years & 4.2500 & .98058 & & & \\
\hline & $7-9$ years & 3.4286 & .75593 & & & \\
\hline & $10-12$ years & 3.3684 & 111607 & & & \\
\hline & $13-15$ years & 4.2727 & .90453 & & & \\
\hline & $16-18$ years & 4.2500 & .46291 & & & \\
\hline & 19 years and above & 4.0652 & .82737 & & & \\
\hline \multirow{7}{*}{$\begin{array}{l}\text { 27. Introductory } \\
\text { documents are prepared } \\
\text { for each training seminar }\end{array}$} & $1-3$ years & 3.2703 & .79893 & \multirow{7}{*}{3.248} & \multirow{7}{*}{$.005^{*}$} & \multirow{7}{*}{$\begin{array}{l}\text { Tamhane TestSignificant difference was } \\
\text { found between 1-3 and 4-6 years, } 4-6 \text { and } \\
7-9 \text { years }\end{array}$} \\
\hline & 4-6 years & 3.8750 & .91111 & & & \\
\hline & $7-9$ years & 2.8571 & .86444 & & & \\
\hline & $10-12$ years & 3.4211 & 1.07061 & & & \\
\hline & $13-15$ years & 3.9091 & 1.30035 & & & \\
\hline & $16-18$ years & 3.7500 & .88641 & & & \\
\hline & 19 years and above & 3.3913 & 1.10510 & & & \\
\hline
\end{tabular}

$* \mathrm{p}<0.05$.

In Table 13, it was observed that there was a significant difference between the variable of referees' professional experience, and the referees' opinion that adequate practical training is provided in referee training courses $(\mathrm{p}<0.05)$, and this difference was observed between 1-3 and 4-6 years, 4-6 and 10-12 years, 4-6 years and 19 years and above.

In Table 13, it was observed that there was a significant difference between the variable of referees' professional experience, and the referees' opinion that instructors provide an enjoyable time with activities planned in the educational environment $(p<0.05)$, and this difference was observed between 1-3 and 4-6 years, 1-3 and 13-15 years, 4-6 and 10-12 years, $10-12$ and $13-15$ years, $13-15$ and 16-18 years, 4-6 years and 19 years and above, and 13-15 years and 19 years and above.

In Table 13, it was observed that there was a significant difference between the variable of referees' professional experience, and the referees' opinion that the referees participating in the training seminars create a good educational environment among themselves $(\mathrm{p}<0.05)$, and this difference was observed between 1-3 and 4-6 years, 
4-6 and 10-12 years, 7-9 and 10-12 years, $10-12$ and $13-15$ years.

In Table 13, it was observed that there was a significant difference between the variable of referees' professional experience, and the referees' opinion that training seminar program is organized to improve teamwork skills $(\mathrm{p}<0.05)$, and this difference was observed between 1-3 and 4-6 years, 1-3 and 13-15 years, 4-6 and 7-9 years, 4-6 and 10-12 years, 7-9 and 13-15 years, 7-9 and 16-18 years, 10-12 and 13-15 years, 7-9 years and 19 years and above, 10-12 years and 19 years and above.

In Table 13, it was observed that there was a significant difference between the variable of referees' professional experience, and the referees' opinion that opinions of the experts were taken during the planning of training program $(\mathrm{p}<0.05)$, and this difference was observed between 1-3 and 4-6 years, 1-3 and 13-15 years, 1-3 years and 19 years and above, 4-6 and 7-9 years, 4-6 and 10-12 years, 7-9 and 13-15 years, 7-9 and 16-18 years, 10-12 and 13-15 years, 7-9 years and 19 years and above, 10-12 years and 19 years and above.

In Table 13, it was observed that there was a significant difference between the variable of referees' professional experience, and the referees' opinion that lessons given in training seminars are planned in an orderly manner $(\mathrm{p}<0.05)$, and this difference was observed between $1-3$ and 4-6 years, 1-3 and 13-15 years, $1-3$ years and 19 years and above, $4-6$ and 7-9 years, $4-6$ and $10-12$ years, $7-9$ and $13-15$ years, $10-12$ and $13-15$ years, $10-12$ and $16-18$ years, $10-12$ years and 19 years and above.

In Table 13, it was observed that there was a significant difference between the variable of referees' professional experience, and the referees' opinion that various measurement tools were used to determine the needs of the referees during the preparation of training programs $(\mathrm{p}<0.05)$, and this difference was observed between 1-3 and 4-6 years, $1-3$ and 7-9 years, $1-3$ and $10-12$ years, $4-6$ and $7-9$ years, $4-6$ and $10-12$ years, 7-9 and $13-15$ years, 7-9 years and 19 years and above, 10-12 and 13-15 years, 10-12 years and 19 years and above.

In Table 13, it was observed that there was a significant difference between the variable of referees' professional experience, and the referees' opinion that managers exhibit positive attitudes and behaviors in solving problems related to the training seminar $(\mathrm{p}<0.05)$, and this difference was observed between 1-3 and 4-6 years, 1-3 and 10-12 years, 4-6 and 7-9 years, 4-6 and 10-12 years, 7-9 and 13-15 years, 7-9 and 16-18 years, 7-9 years and 19 years and above, $10-12$ and $13-15$ years, $10-12$ and $16-18$ years, $10-12$ years and 19 years and above.

In Table 13, it was observed that there was a significant difference between the variable of referees' professional experience, and the referees' opinion that introductory documents are prepared for each training seminar $(\mathrm{p}<0.05)$, and this difference was observed between 1-3 and 4-6 years, and 4-6 and 7-9 years. 
Table 14. One-way ANOVA test results related to the variable of educational level of swimming referees

\begin{tabular}{|c|c|c|c|c|c|c|}
\hline Items & Education Level & $\mathrm{X}$ & $\mathrm{Sd}$ & $\mathrm{F}$ & $\mathrm{p}$ & Difference (LSD) \\
\hline \multirow{5}{*}{$\begin{array}{l}\text { 7. Instructors give } \\
\text { importance to the opinions } \\
\text { and ideas of the referees }\end{array}$} & High School & 1.9804 & 1.06752 & & & \multirow{5}{*}{$\begin{array}{c}\text { Significant difference was found } \\
\text { between bachelor's degree and } \\
\text { master's degree }\end{array}$} \\
\hline & Associate Degree & 1.8824 & 1.03762 & & & \\
\hline & Bachelor's Degree & 1.6729 & .92935 & 2.707 & $.046^{*}$ & \\
\hline & Master's Degree & 2.3000 & 1.21828 & & & \\
\hline & Total & 1.8396 & 1.02237 & & & \\
\hline \multirow{5}{*}{$\begin{array}{l}\text { 11. The buildings and } \\
\text { facilities owned by the } \\
\text { institution are suitable for } \\
\text { education }\end{array}$} & High School & 2.3333 & 1.21106 & \multirow{5}{*}{3.485} & \multirow{5}{*}{$.017 *$} & \multirow{5}{*}{$\begin{array}{c}\text { Tamhane Test } \\
\text { Significant difference was found } \\
\text { between high school and bachelor's } \\
\text { degree }\end{array}$} \\
\hline & Associate Degree & 2.0294 & 1.02942 & & & \\
\hline & Bachelor's Degree & 1.7850 & .85812 & & & \\
\hline & Master's Degree & 1.9500 & 1.09904 & & & \\
\hline & Total & 1.9717 & 1.02071 & & & \\
\hline \multirow{5}{*}{$\begin{array}{l}\text { 17. Different abilities and } \\
\text { educational levels of } \\
\text { referees are taken into } \\
\text { consideration during the } \\
\text { preparation and conduction } \\
\text { of training seminars }\end{array}$} & High School & 2.2157 & 1.40447 & \multirow{5}{*}{3.566} & \multirow{5}{*}{$.015^{*}$} & \multirow{5}{*}{$\begin{array}{c}\text { Tamhane Test } \\
\text { Significant difference was found } \\
\text { between high school and bachelor's } \\
\text { degree }\end{array}$} \\
\hline & Associate Degree & 1.7353 & .99419 & & & \\
\hline & Bachelor's Degree & 1.5981 & .96992 & & & \\
\hline & Master's Degree & 1.9000 & 1.29371 & & & \\
\hline & Total & 1.7972 & 1.14428 & & & \\
\hline \multirow{5}{*}{$\begin{array}{l}\text { 18. The date of training } \\
\text { seminars is suitable for } \\
\text { referees }\end{array}$} & High School & 3.7843 & 1.20522 & \multirow{5}{*}{3.296} & \multirow{5}{*}{$.021 *$} & \multirow{5}{*}{$\begin{array}{c}\text { Significant difference was found } \\
\text { between high school and master's } \\
\text { degree, associate degree and master's } \\
\text { degree, bachelor's degree and master' } \\
\text { degree }\end{array}$} \\
\hline & Associate Degree & 3.5294 & .96091 & & & \\
\hline & Bachelor's Degree & 3.4766 & 1.12724 & & & \\
\hline & Master's Degree & 2.8500 & 1.22582 & & & \\
\hline & Total & 3.5000 & 1.14990 & & & \\
\hline
\end{tabular}

$* \mathrm{p}<0.05$

In Table 14, it was observed that there was a significant difference between the variable of referees' educational level, and the referees' opinion that instructors give importance to the opinions and ideas of the referees $(\mathrm{p}<0.05)$, and this difference was observed between bachelor's degree and master's degree.

In Table 14, it was observed that there was a significant difference between the variable of referees' educational level, and the referees' opinion that the buildings and facilities owned by the institution are suitable for education $(\mathrm{p}<0.05)$, and this difference was observed between high school and bachelor's degree.

In Table 14, it was observed that there was a significant difference between the variable of referees' educational level, and the referees' opinion that different abilities and educational levels of referees are taken into consideration during the preparation and conduction of training seminars $(\mathrm{p}<0.05)$, and this difference was observed between high school and bachelor's degree.

In Table 14, it was observed that there was a significant difference between the variable of referees' educational level, and the referees' opinion that the date of training seminars is suitable for referees $(p<0.05)$, and this difference was observed between high school and bachelor's degree, associate degree and master's degree, and bachelor's degree and master's degree. 
Table 15. One-way ANOVA test results related to swimming referees' reasons to become a referee

\begin{tabular}{|c|c|c|c|c|c|c|}
\hline Items & $\begin{array}{c}\text { The Reasons to Become a } \\
\text { Referee }\end{array}$ & $\mathrm{X}$ & $\mathrm{Sd}$ & $\mathrm{F}$ & $\mathrm{p}$ & Difference \\
\hline \multirow{4}{*}{$\begin{array}{l}\text { 6. Instructors influence } \\
\text { referees with their positive } \\
\text { attitudes and behaviors }\end{array}$} & a. Social Activity & 2.0313 & 1.32100 & \multirow{4}{*}{3.608} & \multirow{4}{*}{$.014 *$} & \multirow{4}{*}{$\begin{array}{c}\text { Tamhane Test } \\
\text { Significant difference was } \\
\text { found between a and d }\end{array}$} \\
\hline & b. Ex-swimmer & 1.5625 & .98169 & & & \\
\hline & c. Additional Work & 1.5714 & .97590 & & & \\
\hline & d. Passion & 1.4954 & .89880 & & & \\
\hline \multirow{4}{*}{$\begin{array}{l}\text { 25. Managers exhibit } \\
\text { positive attitudes and } \\
\text { behaviors in solving } \\
\text { problems related to the } \\
\text { training seminar }\end{array}$} & a. Social Activity & 3.8750 & .80672 & \multirow{4}{*}{3.061} & \multirow{4}{*}{$.029 *$} & \multirow{4}{*}{$\begin{array}{c}\text { LSD Test } \\
\text { Significant difference was } \\
\text { found between a and } \mathrm{c}, \mathrm{b} \text { and } \\
\mathrm{c} \text {, and } \mathrm{c} \text { and } \mathrm{d}\end{array}$} \\
\hline & b. Ex-swimmer & 4.0625 & 1.01401 & & & \\
\hline & c. Additional Work & 3.0000 & 1.29099 & & & \\
\hline & d. Passion & 3.9817 & .84964 & & & \\
\hline
\end{tabular}

In Table 15, it was observed that there was a significant difference between the variable of referees' reason to become a referee, and the referees' opinion that instructors influence referees with their positive attitudes and behaviors $(\mathrm{p}<0.05)$, and it was observed between the options of a and $\mathrm{d}$.

In Table 15, it was observed that there was a significant difference between the variable of referees' reason to become a referee, and the referees' opinion that managers exhibit positive attitudes and behaviors in solving problems related to the training seminar $(\mathrm{p}<0.05)$, and it was observed between the options of a and $\mathrm{c}, \mathrm{b}$ and $\mathrm{c}, \mathrm{c}$ and $\mathrm{d}$.

Table 16. T-test results related to satisfaction level of swimming referees

\begin{tabular}{|c|c|c|c|c|c|}
\hline Items & Satisfaction Level & $\mathrm{X}$ & $\mathrm{Sd}$ & $\mathrm{t}$ & $\mathrm{p}$ \\
\hline $\begin{array}{l}\text { 4. Instructors are aware of individual differences of } \\
\text { the referees, and they plan course accordingly }\end{array}$ & $\begin{array}{c}\text { Satisfied } \\
\text { Undecided }\end{array}$ & $\begin{array}{l}1.9024 \\
3.0000\end{array}$ & $\begin{array}{c}.91300 \\
1.52753\end{array}$ & -3.050 & $.003 *$ \\
\hline $\begin{array}{l}\text { 19. Managers, instructors and referees are aware of } \\
\text { the program activities conducted within the } \\
\text { institution }\end{array}$ & $\begin{array}{l}\text { Satisfied } \\
\text { Undecided }\end{array}$ & $\begin{array}{l}3.6878 \\
2.8571\end{array}$ & $\begin{array}{l}.94459 \\
.69007\end{array}$ & 2303 & $.022 *$ \\
\hline $\begin{array}{l}\text { 22. Opinions of the experts were taken during the } \\
\text { planning of training program }\end{array}$ & $\begin{array}{c}\text { Satisfied } \\
\text { Undecided }\end{array}$ & $\begin{array}{l}3.5659 \\
2.7143\end{array}$ & $\begin{array}{l}.95579 \\
.75593\end{array}$ & 2.331 & $.021 *$ \\
\hline $\begin{array}{l}\text { 24. Various measurement tools were used to } \\
\text { determine the needs of the referees during the } \\
\text { preparation of training programs }\end{array}$ & $\begin{array}{l}\text { Satisfied } \\
\text { Undecided }\end{array}$ & $\begin{array}{l}3.8341 \\
3.0000\end{array}$ & $\begin{array}{l}.92451 \\
1.15470\end{array}$ & 2.329 & $.021 *$ \\
\hline $\begin{array}{l}\text { 25. Managers exhibit positive attitudes and } \\
\text { behaviors in solving problems related to the training } \\
\text { seminar }\end{array}$ & $\begin{array}{l}\text { Satisfied } \\
\text { Undecided }\end{array}$ & $\begin{array}{l}3.9659 \\
2.8571\end{array}$ & $\begin{array}{l}.86535 \\
1.06904\end{array}$ & 3.309 & $.001 *$ \\
\hline
\end{tabular}

$* \mathrm{p}<0.05$.

In Table 16, it was observed that there was a significant difference between the variable of referees' satisfaction level, and the referees' opinion that instructors are aware of individual differences of the referees, and they plan course accordingly $(p<0.05)$, and it was observed that those who were undecided were more likely to participate in Item 4 than those who were satisfied.

In Table 16, it was observed that there was a significant difference between the variable of referees' satisfaction level, and the referees' opinion that managers, instructors and referees are aware of the program activities conducted within the institution $(\mathrm{p}<0.05)$, and it was observed that those who were satisfied were more likely to participate in Item 19 than those who were undecided.

In Table 16, it was observed that there was a significant difference between the variable of referees' satisfaction level, and the referees' opinion that opinions of the experts were taken during the planning of training program $(p<0.05)$, and it was observed that those who were satisfied were more likely to participate in Item than those who were undecided.

In Table 16, it was observed that there was a significant difference between the variable of referees' satisfaction level, and the referees' opinion that various measurement tools were used to determine the needs of the referees 
during the preparation of training programs $(\mathrm{p}<0.05)$, and it was observed that those who were satisfied were more likely to participate in Item 24 than those who were undecided.

In Table 16, it was observed that there was a significant difference between the variable of referees' satisfaction level, and the referees' opinion that managers exhibit positive attitudes and behaviors in solving problems related to the training seminar $(p<0.05)$, and it was observed that those who were satisfied were more likely to participate in Item 25 than those who were undecided.

\section{Discussion}

In the study, the opinions of licensed swimming referees, who actively serve in Turkish Swimming Federation, regarding referee training process were examined and their expectations levels were tried to be determined. In the study, I-26, I-3, I-9, I-25, I-23, I-15, I-1, I-24, I-19, I-29 and I-22 were the items that reported positive opinion, respectively. The percentages of participation in these items are $82.5 \%, 77.8 \%, 75.5 \%, 69.8 \%, 67.0 \%, 64.9 \%$, $64.6 \%, 63.7 \%, 58 \%, 56.6 \%$ and $53.7 \%$, respectively. On the other hand, I-16, I-5, I-10, I-6, I-12, I-17, I-4, I-7, I-11, I-2 and I-14 were the items that reported negative opinion, respectively. The percentages of participation in these items are $92.5 \%, 92.0 \%, 85.3 \%, 83.5 \%, 82.6 \%, 80.2 \%, 79.3 \%, 78.3 \%, 78.3 \%, 78.3 \%, 71.7 \%$ and $66.6 \%$, respectively.

Although there are very few studies on the referees' training process and expectation levels, the findings are discussed and compared within the framework of literature.

\subsection{The Results Related to Efficiency of Candidate Referee Training Courses}

When referees' opinion on the efficiency of candidate referee training courses were examined, it was observed that adequate practical training is provided, but the number of trainees in the training courses was not suitable for a good educational environment. Considering the opinion that candidates receive adequate practical training in referee training courses, significant differences were found in all age groups of referees except between 13-15 and 16-18 years.

Karaçam (2013), similarly to this study, reported in his study on basketball referees that the opinion of the candidate referee training courses was adequate for all groups except referees whose professional experience was between $12-14$ years.

\subsection{The Results Related to the Proficiency of the Instructors Working in the Training Seminars}

When the opinions of the referees about the proficiency of the instructors is examined, the referees think that instructors are willing to work overtime with referees when needed, and they have academic knowledge and experience appropriate to the seminar. However, referees reject the claims that instructors are aware of individual differences of the referees and they plan course accordingly, instructors plan and implement course activities at a high level, instructors give importance to the opinions and ideas of the referees, instructors affect the referees by exhibiting positive attitudes and behaviors, and instructors follow different learning and teaching methods in training seminars.

When similar studies in the literature are compared, it is remarkable that the referees evaluate instructors that they have academic qualification. Kayışoğlu et al. (2010), parallel to this study, stated in their studies on football referees that the instructors have academic knowledge and experience appropriate to the seminar, but they have deficiencies in planning the courses according to individual differences. In addition, contrary to this study, it was emphasized that instructors could affect the referees by exhibiting positive attitudes and behaviors.

\subsection{The Results Related to the Efficiency of Training Seminars and Educational Environment}

When the opinions of the referees about educational environment were examined, referees claim that buildings and facilities owned by the institution are not suitable for education, The seminar building, and equipment are not well organized for the use of instructors and referees, and The physical structure of the classroom environments where training seminars are conducted is not suitable for good education.

Müniroğlu (1988) and Kayışoğlu et al. (2010), in parallel with this study, stated that the buildings and facilities of the institution are insufficient.

In the study, significant difference was found between the opinions of the referees on the efficiency of the educational environment and the level of education, and accordingly, the idea that referees who have graduated from high school found the educational environment more efficient than referees who have completed bachelor's degree graduates came to the fore.

Kayışoğlu et al. (2010) stated that there was no significant difference between the opinions of referees, and their 
educational levels, but the referees who graduated from bachelor's degree and master's degree found that training process was less efficient than referees who have completed high school and associate degree.

Karaçam (2013) reported that basketball referees found the efficiency of educational environment enough and in the light of educational level, referees at the level of doctorate found the efficiency of the education environment less adequate in contrast to the other referees.

In the literature, it is seen in the studies conducted with the referees of different branches that as the level of education increases, the expectation levels of the referees increase accordingly.

\subsection{The Results Related to the Planning of Training Seminars}

When referees' opinion on the planning of the training seminars were examined, it was considered that lessons given in training seminars are planned in an orderly manner, the aims of training seminar were clearly determined, managers, instructors and referees are aware of the program activities conducted within the institution, and opinions of the experts were taken during the planning of training program. It was also observed that various measurement tools were used to determine the needs of the referees during the preparation of training programs, managers exhibit positive attitudes and behaviors in solving problems related to the training seminar, and training program in the seminars is clearly identified and submitted to the referees' information. In addition, it was found that courses given in the training seminars were not clear and understandable, and different abilities and educational levels of referees are taken into consideration during the preparation and conduction of training seminars.

Kayışoğlu (2008), in parallel with this study, suggest that managers exhibited positive attitudes and behaviors in solving problems related to the training seminar, the opinions of the experts were taken during the planning of training program, and different abilities and educational levels of referees are taken into consideration during the preparation and conduction of training seminars. Similar to the literature, it is considerable that different abilities and educational levels of referees should be taken into consideration during the preparation of training seminars.

Kayışoğlu (2008) also reported that, contrary to this research, football referees refused that the courses given in the training seminars are clear and understandable and the needs of the referees was determined during the preparation of training seminars.

In the research, it was found that there was significant difference between referees' opinion on the planning of the training seminars and professional experience. Therefore, it was determined that referees who have professional experience of 4-6 years, 13-15 years and 16-18 years found the planning of the training seminars more adequate than the other referees. There was also significant difference between referees' opinion on the planning of the training seminars and satisfaction levels of referees, and it was found that those who were satisfied found that the planning of the training seminars was more adequate than the undecided ones.

When the literature is examined, it is seen that the variable of professional experience is effective in the planning of training seminars. Karaçam (2013), in parallel with this research, consider that referees' professional experience and it is concluded that the planning of training seminars was found adequate in all age groups except 12-14 years.

In terms of gender variable, considering that opinions of experts were taken into consideration during the planning of training programs, it was found that female referees agreed with the opinion more than male referees.

\subsection{The Results Related to the Evaluation of Training Seminars}

When the opinions of the referees on the evaluation of the training seminars were examined, it was found that the evaluation activities were carried out at the end of the implementation.

Kayışoğlu et al. (2010) also reported that, contrary to this research, referees do not agree with the opinion that lessons given in training seminars are evaluated in an orderly manner. It is estimated that this is due to the fact that federations in different branches have specific evaluation activities.

\section{Conclusion and Suggestions}

In this study, it was found that some variables of swimming referees had an effect on the referees' training processes, and it was concluded that referees' opinions about referee training process were generally positive and negative.

1) Reducing the number of trainees in candidate referee training courses and completing their deficiencies by assigning an observer or guide referee to any competition to be managed by the candidate referees will be appropriate for the efficiency of the candidate referee courses.

2) Instructors working in training seminars will improve the quality of education by using effective teaching 
methods to communicate effectively and correctly and planning of the training seminars considering the individual differences of the referees.

3) Revisions to increase the number of lecture hours and to make the course contents comprehensible by preparing different course contents appropriate to the referees of different abilities, education level and experience will contribute to the efficiency of education.

4) It is considered that an appropriate educational environment will be provided with the improvement of the physical conditions of the educational environment.

5) The education level of the referees can be maximized according to the related department by opening the Department of Refereeing Education in the Faculties of Sport Sciences or Schools of Physical Education and Sports or by including the referee training courses in the programs in these departments.

\section{Acknowledgments}

This paper was submitted as an oral paper at the 6th International Congress on Science, Culture and Sports held between 25th-28th April 2018 in Lviv, Ukraine.

\section{References}

Dölek, E. B. (2010). Yüzmenin neden olduğu vücut sıvı dengesindeki değişimlerin yüzme performansina etkileri. Gazi Üniversitesi Sağlık Bilimleri Enstitüsü, Doktora Tezi, Ankara.

Ekmekçi, R. (2008). Basketbol hakemlerinin stres kaynakları ile stresle başa çıkabilme yöntemlerinin tespiti ve önleyici yönetsel uygulamaların geliştirilmesi. Abant İzzet Baysal Üniversitesi Sosyal Bilimler Enstitüsü, Doktora Tezi, Bolu.

Güner, A. G. (2009). Türk A klasman basketbol hakemlerinin vücut kompozisyon değerleri ve reaksiyon zamanlarının incelenmesi. Gazi Üniversitesi Sağlık Bilimleri Enstitüsü, Yüksek Lisans Tezi, Ankara.

Karaçam, A. (2013). Basketbol klasman hakemlerinin eğitim süreçlerinin incelenmesi ve beklenti düzeyleri. Gazi Üniversitesi Eğitim Bilimleri Enstitüsü, Yüksek Lisans Tezi, Ankara.

Kayışoğlu, B. N. (2008). Faal futbol klasman hakemlerinin eğitim süreçlerinin incelenmesi ve beklenti düzeyleri (Türkiye futbol federasyonu 3.bölge örneği). Gazi Üniversitesi Eğitim Bilimleri Enstitüsü, Doktora Tezi, Ankara.

Kayışoğlu, N. B., Günay, M., \& Kara, E. (2010). Faal Futbol Klasman Hakemlerinin Eğitim Süreçlerinin İncelenmesi ve Beklenti Düzeyleri. Selçuk University Journal of Physical Education and Sport Science, 12(2), 104-112.

Müniroğlu, S. (1988). Ankara'daki klasman futbol hakemlerinin eğitimi. Gazi Üniversitesi Sosyal Bilimler Enstitüsü, Yüksek Lisans Tezi, Ankara.

Özdemir, S. (2002). Eğitimde örgütsel yenileşme. 5. Baskı, Pegem Yayınları, Ankara.

\section{Copyrights}

Copyright for this article is retained by the author(s), with first publication rights granted to the journal.

This is an open-access article distributed under the terms and conditions of the Creative Commons Attribution license (http://creativecommons.org/licenses/by/4.0/). 